\title{
Zonasi Distribusi Tanaman Hutan di Taman Nasional Gunung Semeru Berdasarkan Integrasi Nilai Indeks Vegetasi dan Digital Elevation Model
}

\author{
Aqilla Fitdhea Anesta ${ }^{1}$, Angga Febry Fatman ${ }^{1}$, Mamad Sugandi ${ }^{1}$ \\ ${ }^{1}$ Jurusan Teknik Geodesi dan Geomatika, Universitas Lampung, Jl. Prof. Dr. Ir. Sumantri Brojonegoro, Bandar Lampung, Lampung \\ 35141
}

Dikirim:
20 April 2020
Direvisi:
15 Juli 2020
Diterima:
10 Agustus 2020
* Email Korespondensi:
aqilla.fitdhea3006@students.unila.ac.id
(1) (i) (2)

Abstrak: Penelitian ini menggunakan ilmu penginderaan jauh, yang mana memungkinkan kita dapat melakukan penelitian tanpa harus datang langsung ke lokasi dan diharapkan mendapatkan data yang memiliki cakupan yang luas dari citra satelit. Tujuan penelitian ini adalah untuk mengetahui persebaran vegetasi berdasarkan ketinggian tempat dan nilai indeks vegetasi pada TN-BTS. Data dalam penelitian ini adalah citra Landsat 8 bulan November 2019 dan data ketinggian dari DEMNAS. Data tersebut diolah dengan menggunakan Normalized Difference Vegetation Index (NDVI) dan reklasifikasi ketinggian kedalam tiga zona ketinggian, antara lain sub-montana, montana dan sub-alpin. Integrasi kedua data tersebut akan menghasilkan peta distribusi tanaman hutan terhadap ketiga zona ketinggian. Studi menunjukkan bahwa semakin bertambahnya ketinggian tempat akan diikuti dengan pengurangan nilai NDVI. Ini menunjukkan bahwa berkurangnya vegetasi baik kerapatan, jenis dan kualitas tumbuhnya. Demikian halnya dengan semakin rendah suatu ketinggian tempat akan diikuti dengan tingginya nilai NDVI dan vegetasi yang nampak akan lebih rapat dan lebih beragam jenisnya. Tetapi, nilai NDVI hanya mempunyai sedikit pengaruh terhadap zonasi ketinggian. Hasil yang diharapkan dari studi ini adalah menunjukkan karakteristik utuh dari hubungan NDVI dengan ketinggian pada ketiga zona yang dikaji.

Kata kunci: DEMNAS, Distribusi Vegetasi, Gunung Semeru, Landsat 8 , NDVI.

\begin{abstract}
This study aims to determine the distribution of vegetation based on altitude and vegetation index value in TN-BTS. The data used are Landsat 8 satellite imagery recording in July 2019 and altitude data from SRTM 1 Arc Second. The data is processed using Normalized Difference Vegetation Index (NDVI) and reclassification of altitude into three altitude zones, including sub-montane, montane and sub-alpine. Integration of the two data will produce a map of the distribution of forest plants to the three altitude zones. Studies show that increasing altitude will be followed by a reduction in NDVI values. This shows that the reduction in vegetation both density, type and quality of growth. Likewise, a lower altitude will be followed by a high NDVI value and vegetation that will appear to be denser and more diverse in types. However, NDVI values have little effect on altitude zoning. The expected outcome of this study is to show the intact characteristics of the relationship between NDVI and height in the three zones studied.
\end{abstract}

Keywords: Landsat 8, Mount Semeru, NDVI, SRTM 1 Arc Second, Vegetation Distribution.

\section{PENDAHULUAN}

\subsection{Latar Belakang}

Indonesia merupakan negara kepulauan di dunia yang mempunyai hutan tropis yang besar. Lalu, kaya juga dengan keanekaragaman hayatinya. Persebaran tumbuhan di hutan tropis Indonesia ternyata lebih dari $12 \%$ (30.000) dari yang ada dimuka bumi (250.000). Tumbuhtumbuhan mempunyai banyak manfaat dalam kehidupan. Seperti, untuk pangan, papan, energi, sandang dan lainnya. Tumbuhan pun telah banyak dimanfaatkan sedari dulu oleh nenek moyang kita. (Alfarisi, 2012).

Hutan adalah salah satu dari objek tumbuhan yang sepatutnya harus terus dikaji dan dikembangkan. Pohon merupakan komponen utama dari hutan yang berperan penting dalam penunjang kehidupan, sumber air, sumberdaya pembangunan dan sumber pemasukan negara (Desmann dkk, 1977).

Hutan berperan penting sebagai penunjang kehidupan di alam ini. Hutan juga menghasilkan bahan non kayu dan jasa terhadap lingkungan. Beberapa contoh hasil hutan non kayu adalah umbiumbian, madu, rotan, kayu manis, bahan obatobatan, dan lainnya, Lingkungan pun merasakan dampak positif dari adanya hutan, seperti menampung air, mencegah banjir, mengurangi erosi dan sedimentasi, sumber keanekaragaman hayati dan menyerap karbon sehingga mengurangi udara kotor, serta sebagai tempat tinggal satwa dan makhluk hidup lainnya (Barr dkk., 2001). Pohon yang tinggi mempunyai peranan yang vital dalam menjaga kesuburan tanah bagi vegetasi hutan

Mencegah erosi dan menghijaukan lahan yang tandus merupakan salah satu peran hutan. Oleh karena itu perlu dikelola menggunakan sistem 
zonasi yang dapat dimanfaatkan untuk penelitian, pengembangan ilmu pengetahuan. Untuk mengetahui keanekaragaman vegetasi suatu hutan, maka perlu dilakukan riset untuk mempelajari vegetasi hutan. Salah satunya adalah vegetasi hutan alami yang berada dikawasan Taman Nasional Bromo Tengger Semeru.

Persebaran vegetasi di TN-BTS banyak dan sangat heterogen. Vegetasi merupakan kumpulan tumbuhan, biasanya terdiri atas beberapa jenis yang hidup bersama pada suatu habitat. Dalam kehidupan pada suatu habitat terdapat interaksi yang kuat, baik diantara sesama penyusun vegetasi itu maupun dengan organisme lainnya sehingga merupakan suatu sistem yang hidup dinamis (Marsono, 1977).

Semakin tinggi suatu daratan, semakin sedikit tanaman yang dapat dibudidayakan (Junghuhn, 1850). Teori tersebut menjadi acuan dalam riset ini, untuk mengamati zonasi persebaran tanaman di TN-BTS.

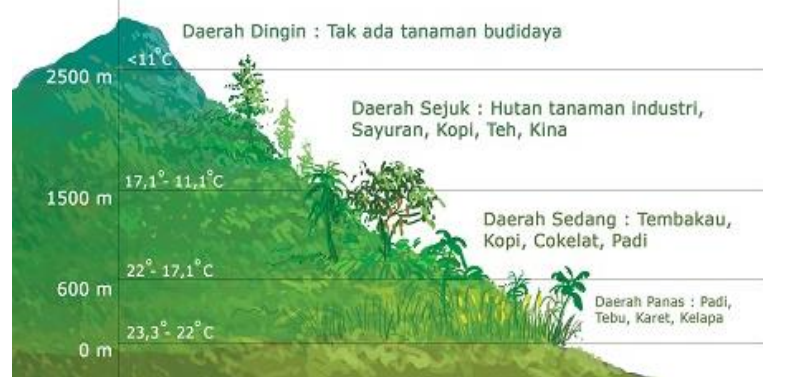

Gambar 1. Teori Iklim Junghuhn (Sumber: Suastini, 2015)

Gunung Semeru juga merupakan gunung berapi tertinggi ketiga di Indonesia setelah Gunung Kerinci di Jambi dan Gunung Rinjani di Nusa Tenggara Barat. Aktivitas vukanik juga telah menyebabkan perbedaan formasi vegetasi hutan hujan pegunungan. Hutan sub pegunungan (sub montana) dimulai di atas ketinggian 1000 mdpl.

Salah satu faktor penting pembentukan hutan adalah suhu yang rendah dan terbentuknya kabut yang sering menyelimuti atap tajuk. Kabut ini meningkatkan kelembaban udara, dengan demikian menurunkan laju evapotranspirasi. Dengan bertambah tingginya suatu tempat, pohonpohon cenderung pendek dan banyak bercabang.

Di hutan pegunungan terdapat zona vegetasi, dengan jenis, struktur dan bentuk morfologi yang berbeda. Zona vegetasi tersebut dapat dikenali di semua gunung di daerah tropis walaupun tidak hanya ditentukan oleh ketinggian. Di gunung yang tidak begitu tinggi, semua zona vegetasi lebih sempit, sedangkan di gunung yang tinggi, atau di bagian tengah suatu pegunungan, zona-zona itu lebih luas (MacKinnon dkk., 2000).

Pepohonan memiliki diameter batang yang besar dan bentuk batang tegak. Kondisi batang sedikit atau bebas dari lumut. Lapisan utama kanopi dapat mencapai tinggi 30-40 m, dan masih dijumpai pohon pencuat hingga $60 \mathrm{~m}$. Liana dan epifit di zona sub - Montana sering ditemukan menempel di pepohonan. Jenis pohon yang sering dan mudah ditemukan di zona sub pegunungan, diantaranya rasamala Altingia excelsa, Jamuju Podocarpus imbricatus, Ki Putri P. Neriifolius.

Zona berikutnya adalah montana (zona pegunungan) dengan ketinggian 1500 - 2400 mdpl. Zona ini dicirikan dengan penutupan vegetasi yang rapat, diameter batang mengecil, dan banyak ditempeli lumut dan paku-pakuan. Tinggi pohon hanya setinggi lapisan kedua pada zona sub montana.

Zona ini memiliki keberagaman jenis pohon yang semakin sedikit. Semakin ke atas, formasi vegetasi semakin terbuka lebar. Sinar matahari memungkinkan masuk ke bagian tanah hutan, sehingga keberadaan rumput dan terna semakin banyak.

Semakin ke atas gunung pada zona sub alpin, pepohonan semakin pendek. Bentuk batang tidak teratur. Kerapatan tumbuhannya pun menyebar, membuat banyaknya ruang kosong. Tinggi pohon berkisar 8-20 m dengan komposisi spesies lebih sedikit dibandinkan dengan dua zona di bawahnya.

Semakin ke atas, kanopi pohon semakin pendek. Tumbuhan liana juga semakin jarang dan digantikan oleh Brophytes (lumut), lumut kerak, bambu, dan perdu (Heaney 2001 dalam Ghazoul and Sheil 2010).

Dalam pertumbuhan dan persebaran tanaman, tinggi tempat berpengaruh terhadap suhu udara dan intensitas cahaya (Sulistyono, 1995). Suhu dan cahaya yang masuk akan semakin kecil dengan semakin tingginya tempat tumbuh. Berkurangnya suhu dan cahaya yang masuk dapat menghambat pertumbuhan karena proses fotosintesis terganggu. Area yang memiliki elevasi tinggi, jumlah konsentrasi $\mathrm{CO}_{2}$ relatif lebih kecil bila dibandingkan pada daerah yang lebih rendah. Hal ini menyebabkan fotosintesis menjadi lambat, karbohidrat untuk pertumbuhan menjadi berkurang, dan tinggi tanaman akan berkurang.

Intensitas tanaman pada suatu wilayah pada citra dapat digambarkan dengan indeks vegetasi. Indeks vegetasi adalah gabungan antara band merah dan band NIR (Near-Infrared Radiation) yang digunakan sebagai acuan keberadaan dan kondisi tumbuhan (Lillesand \& Kiefer 1997). Penggunaan indeks vegetasi yang paling sering adalah NDVI (Normalized Difference Vegetation Index). Perhitungan NDVI didasarkan pada prinsip bahwa tanaman hijau sangat efektif menyerap radiasi di daerah spektrum cahaya tampak (PAR atau Photosynthetically Aktif Radiation), sementara itu tanaman hijau memantulkan radiasi inframerah dekat (Ryan, 1997). Ilmu penginderaan jauh pun memungkinkan kita untuk melakukan penelitian tanpa harus adanya kontak langsung dengan lokasi yang dituju. Lokasi TN-BTS pun dapat dijangkau dengan mudah walau memiliki cakupan wilayah yang luas. 
Berdasarkan penjabaran diatas, penginderaan jauh merupakan salah satu solusi untuk pemantauan area hutan yang sangat luas dan dapat mengetahui informasi mengenai kehutanan menggunakan data dari citra satelit. Oleh karena itu, Riset ini akan fokus pada distribusi dan relasi vegetasi di ketiga zona ketinggian di TN-BTS.

\subsection{Rumusan Masalah}

Berdasarkan pada latar belakang yang telah dijabarkan, maka perumusan masalah yang akan dibahas adalah analisis NDVI di wilayah TN-BTS berdasarkan zonasinya dan korelasi antara NDVI dengan zona ketinggian

\subsection{Maksud dan Tujuan Penelitian}

Maksud dan tujuan penelitian ini adalah untuk mengetahui ketinggian dan kelas kerapatan vegetasi dikawasan TN-BTS. Penelitian ini dapat mengetahui bagian mana yang memiliki distribusi vegetasi yang paling dominan.

\section{BAHAN DAN METODE PENELITIAN}

\subsection{Area Studi}

Studi terkait dengan penelitian ini dilakukan di areal Taman Nasional Gunung Semeru. Taman Nasional Bromo Tengger Semeru merupakan Taman Nasional yang terletak di Jawa Timur, Indonesia, yang terletak di wilayah Kabupaten Pasuruan, Kabupaten Malang, Kabupaten Lumajang dan Kabupaten Probolinggo.

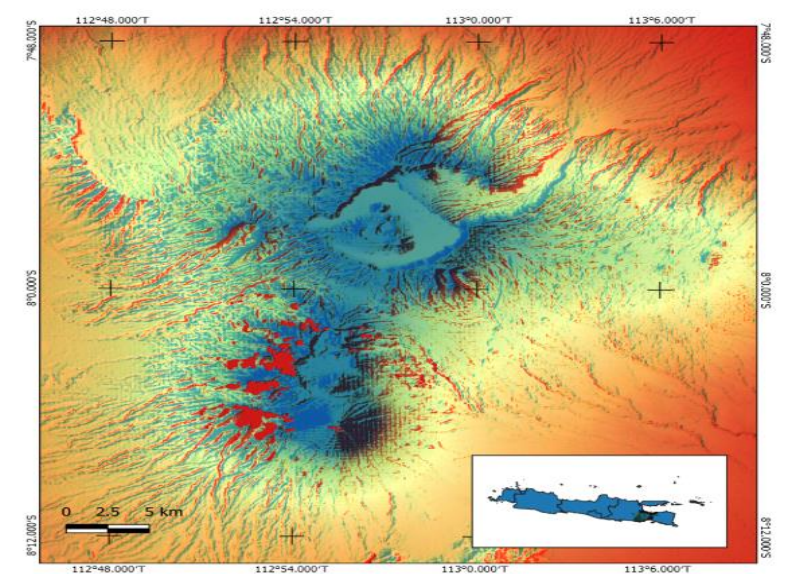

Gambar 2. Area Studi Taman Nasional Gunung Semeru

Taman ini ditetapkan sejak tahun 1982 dengan luas TNBTS adalah $50.276,20 \mathrm{Ha}$, terdiri dari 50.265,95 Ha daratan dan 10,25 Ha perairan yang berupa danau atau ranu. Secara Geografis kawasan TNBTS terletak antara $7^{\circ} 51^{\prime \prime 3} 9^{\prime}$ - 8 8 $^{\circ} 9^{\prime \prime} 35^{\prime}$ LS dan 112 $47^{\circ} " 44^{\prime}-113^{\circ} 77^{\prime \prime} 45^{\prime}$ BT. Area TNBTS berada pada ketinggian 750-3.676 meter dari permukaan laut, keadaan topografinya bervariasi dari bergelombang dengan lereng yang landai sampai berbukit bahkan bergunung dengan derajat kemiringan yang tegak. Suhu udara di TNBTS antara $5^{\circ} \mathrm{C}$ sampai $22^{\circ} \mathrm{C}$.

suhu terendah terjadi pada dini hari di puncak musim kemarau antara $3 \stackrel{\circ}{\circ}-5 \stackrel{\circ}{ } \mathrm{C}$ bahkan dibeberapa tempat sering bersuhu sampai $0 \stackrel{\circ}{ } \mathrm{C}$ (minus) khususnya di Ranukumbolo dan puncak Mahameru. Sedangkan suhu tertinggi antara $20 \stackrel{\circ}{ } \mathrm{C}$ $-22 \stackrel{\circ}{ } \mathrm{C}$ (Departemen Kehutanan, 2009).

\subsection{Data}

Data yang digunakan dalam studi ini terdiri dari dua data. Data pertama adalah data citra Landsat 8 yang diambil pada tanggal 13 Juli 2019, terdiri dari kanal merah dan inframerah dekat. Areal Taman Nasional Gunung Semeru, berada di path 118 dan row 66. Keseluruhan data citra yang terkumpul digunakan untuk menentukan indeks vegetasi pada areal TN-BTS.

Untuk mengetahui korelasi dengan zona ketinggian, maka digunakan data gabungan SRTM 1 Arc Second kabupaten Probolinggo, kabupaten Pasuruan, kabupaten Lumajang dan kabupaten Kepanjen. Data SRTM ini digunakan untuk pembagian nilai indeks vegetasi menjadi tiga zona ketinggian, yakni $<1500 \mathrm{mdpl}, 1500-2400 \mathrm{mdpl}$ dan $>2400$ mdpl.

\subsection{Pengolahan data}

Nilai, pola, dan relasi antara indeks vegetasi dan zona ketinggian dihitung menggunakan Normalized Difference Vegetation Index (NDVI) yang merepresentasikan objek vegetasi yang tumbuh (Rouse dkk., 1974). Nilai NDVI ditentukan berdasarkan perbandingan reflektan dari kanal merah dengan inframerah (Persamaan 1). Hasil yang diperoleh menunjukkan rentang nilai -1 (Tanpa vegetasi) sampai 1 (vegetasi).

$$
\text { NDVI }=(\rho \text { NIR }-\rho \text { Red }) /(\rho \text { NIR }+\rho \text { Red })
$$

Notasi-notasi dalam persamaan (1) dijelaskan dalam alinea setelahnya. Sebagai berkut:

$$
\begin{array}{ll}
\text { NDVI } & =\text { Nilai indeks vegetasi } \\
\rho N I R & =\text { Nilai kanal inframerah dekat } \\
\rho \text { Red } & =\text { Nilai kanal merah }
\end{array}
$$

Setelah perhitungan NDVI, kemudian dilakukan pembagian area menjadi tiga zona sesuai ketinggiannya. Tiga zona tersebut antara lain: submontana( <1500 mdpl), Montana (1500 - 2400 mdpl) dan sub-alpin( >2400 mdpl). Berikut tahapan pengolahan data pada riset ini: 


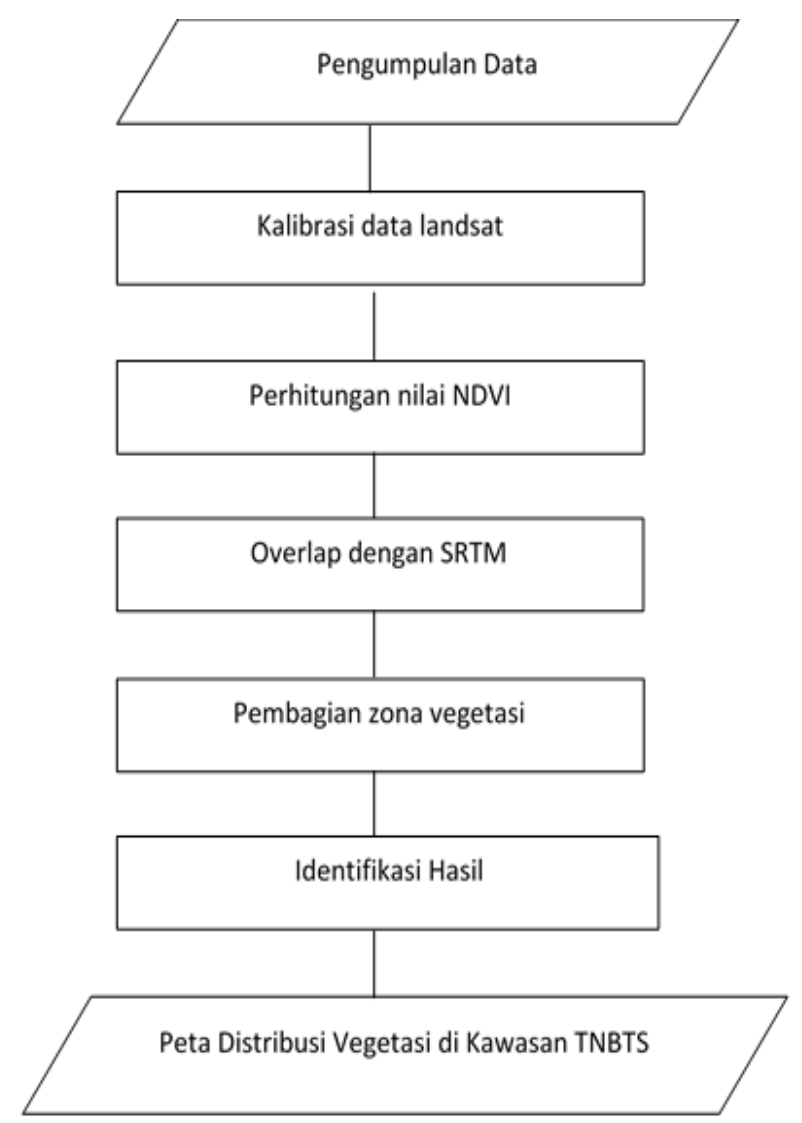

Gambar 3. Diagram Alir Pengolahan Data

Dari hasil perhitungan dengan menggunakan rumus NDVI, kelas kerapatan vegetasi dibagi menjadi 5 kelas. Nilainya mempunyai rentang dari 0,1 sampai dengan 0,72 .

Tabel 1. Nilai NDVI berdasarkan kelompoknya

\begin{tabular}{ll}
\hline Kerapatan vegetasi & Nilai NDVI \\
\hline Vegetasi sangat rapat & $0,72-0,92$ \\
Vegetasi rapat & $0,42-0,72$ \\
Vegetasi Sedang & $0,22-0,42$ \\
Vegetasi jarang & $0,12-0,22$ \\
Non vegetasi & $-0,1-0,22$
\end{tabular}

Relasi antara NDVI dan zona ketinggian tersebut dapat diketahui dengan menghitung nilai koefisien determinasi (R2), berdasarkan pola yang digambarkan pada diagram sebar sehingga diperoleh besarnya tingkat korelasi nilai NDVI dengan zona ketinggian.

\section{HASIL DAN PEMBAHASAN}

\subsection{Bentuk Spasial}

Hasil perhitungan NDVI terlihat lebih tersebar merata di ketinggian $<1500$ mdpl. Area dengan ketinggian < 1500 mdpl disebut zona sub-montana. Area ini pun lebih luas dibandingkan kedua zona ketinggian yang lainnya.
Pada zona ini, didominasi oleh vegetasi rapat. Pada zona ini didominasi oleh beberapa famili tumbuhan diantaranya Anacardiaceae, Burseraceae, Capparaceae, Combretaceae,

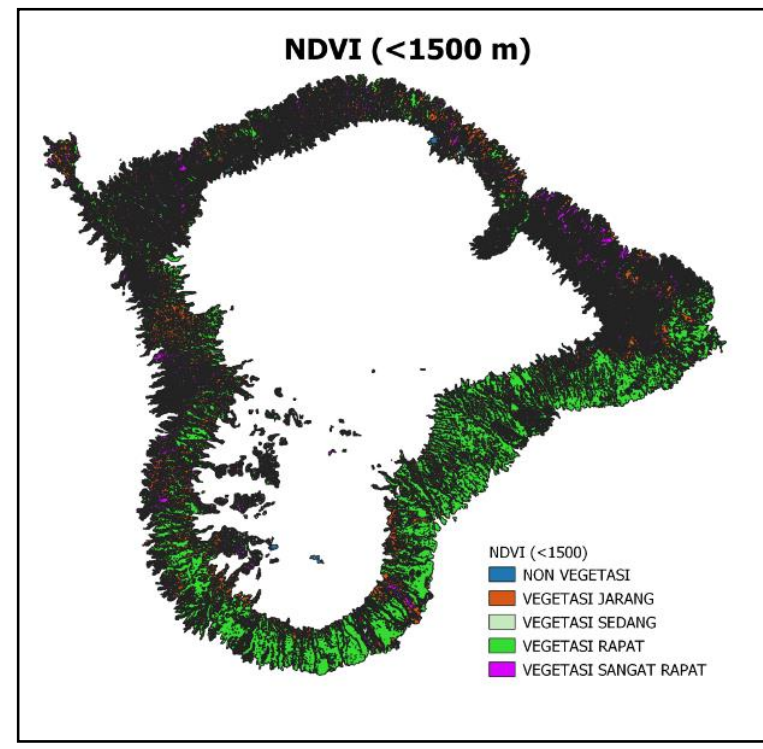

Gambar 4. Bentuk spasial NDVI dengan zona ketinggian 1500 meter dengan jenis vegetasi Dilleniaceae, Dipterocarpaceae, dan Myristicaceae (Arhamsyah, 2015).

Ciri-ciri hutan hujan pegunungan sub-montana, antara lain Berada pada ketinggian 500-1.500 mdpl, Pohonnya tinggi dan daunnya lebat, Kelembapan udara tinggi, Vegetasi tanaman berlapis, sinar matahari tidak bias mencapai dasar hutan, Mempunyai genangan air di dasar hutan, daya regenerasi tinggi, tumbuhan epifit menempel di pepohonan

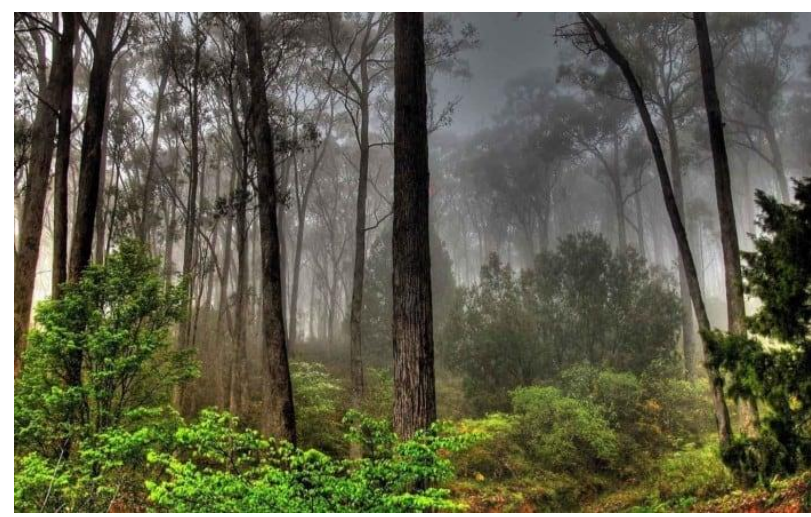

Gambar 5. Hutan Pegunungan Rendah (Agc Indonesia, 2010)

Pada zona kedua merupakan zona montana dengan ketinggian $1500-2400$ mdpl. Dari bentuk spasial, dapat terlihat bahwa vegetasi sangat rapat mendominasi dibagian tengah area. 


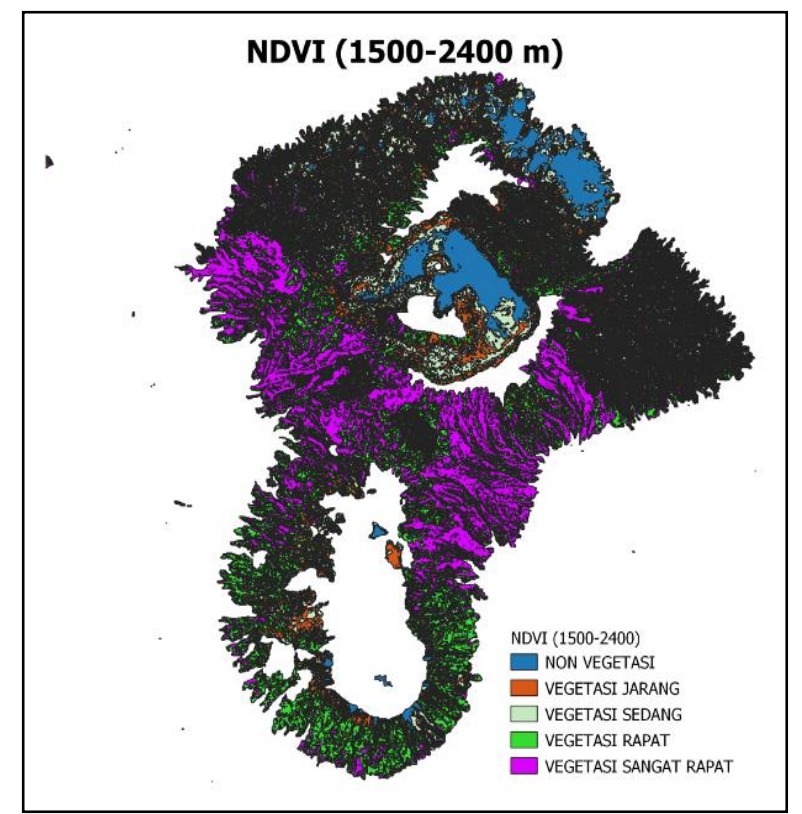

Gambar 6. Bentuk spasial NDVI dengan zona ketinggian lebih dari 1500 - 2400 meter

Ciri-ciri hutan hujan montana sebagai berikut. Berada pada ketinggian 1.500-2.400 m dpl (meter di atas permukaan laut), Tumbuhannya tidak begitu jika dibandingkan dengan hutan hujan pegunungan sub-montana, Biasanya pohon berdiameter lebih besar, daunnya lebih kecil, dan tidak berakar papan, Pohon-pohon yang paling umum dijumpai antara lain berangan/riung, waru batu/waru teja, dan cemara

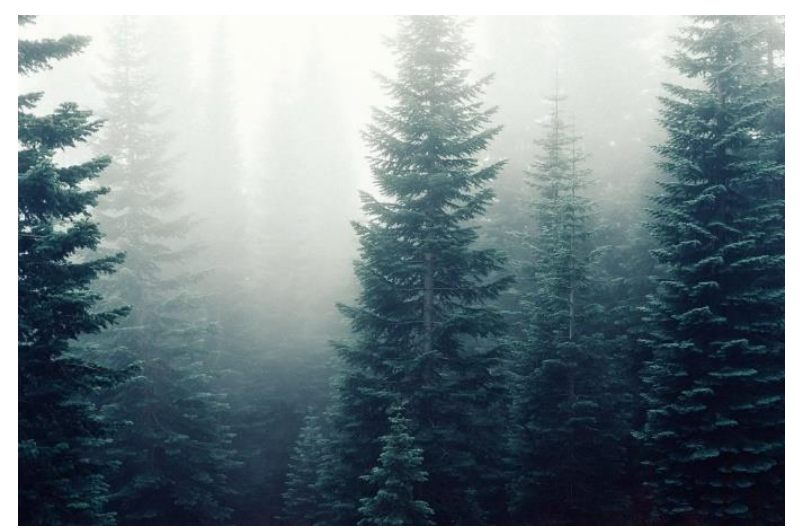

Gambar 7. Pohon Cemara (https://cintaihidup. com/10-manfaat-pohon-cemara-bagi-manusiadan-kesehatan)

Semakin ke puncak gunung disebut zona sub alpin, pepohonan semakin kerdil. Bentuk batang tidak teratur. Kerapatan tumbuh juga menyebar, menciptakan banyak ruang kosong. Tinggi pohon berkisar 8-20 m dengan komposisi spesies lebih sedikit dibandingkan dengan dua zona di bawahnya.

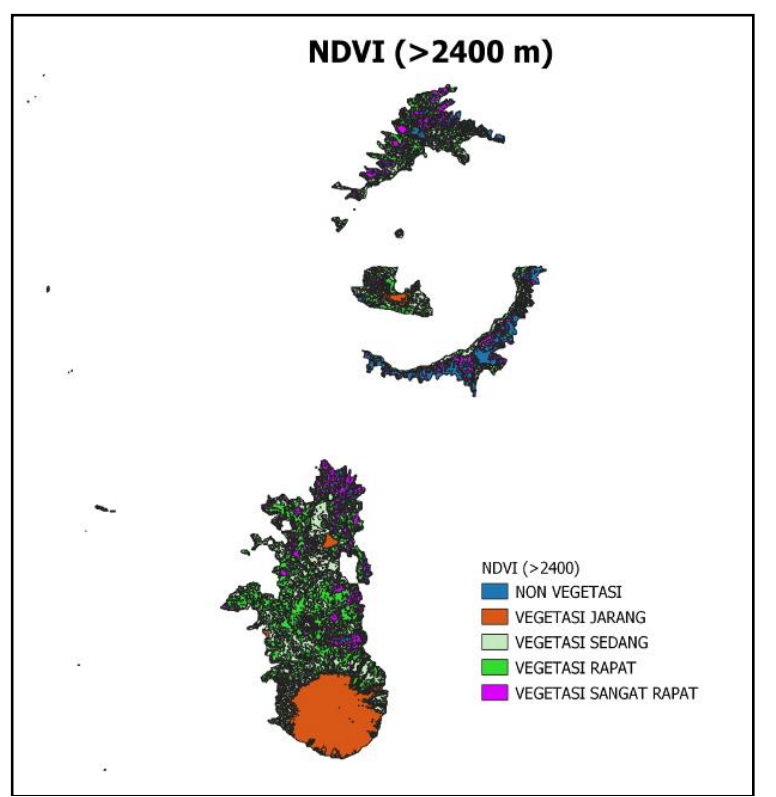

Gambar 8. Bentuk spasial NDVI dengan zona ketinggian lebih dari 2400 meter

Semakin menuju puncak, kanopi pohon semakin pendek. Tumbuhan liana juga semakin jarang dan digantikan oleh Brophytes (lumut), lumut kerak, bambu, dan perdu (Heaney 2001 dalam Ghazoul and Sheil 2010). Ciri-ciri hutan sub-alpin sebagai berikut. Berada pada area dengan ketinggian 2.400-4.000 meter di atas permukaan laut, Pohonnya rapat, tetapi tidak tinggi, Jenis pohon sangat sedikit dengan batang yang membengkok dan dilapisi berjenis-jenis lumut.

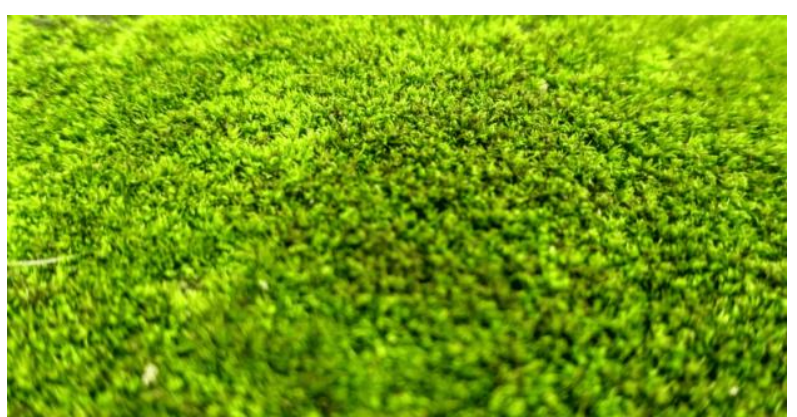

Gambar 9. Lumut ( https://phoenixhillna.org/lumut/)

\subsection{Uji Regresi antara NDVI dan Zona Ketinggian}

Dari hasil regresi antara nilai indeks vegetasi dan zona ketinggian dapat diperoleh hubungan yang sangat kecil antara indeks vegetasi dan zona ketinggian. Dari riset ini diperoleh nilai $R^{2}$ yang sangat kecil. Dari ketiga hasil regresi tersebut, nilai yang paling besar adalah di zona dengan ketinggian $>2400 \mathrm{~m}$ dengan nilai 0,0723 . Kondisi ini terlihat oleh sejalan dengan apa yang disampaikan oleh Junghuhn dalam Fatma (2017). Dimana semakin tinggi suatu daratan, semakin sedikit tanaman yang dapat dibudidayakan. 


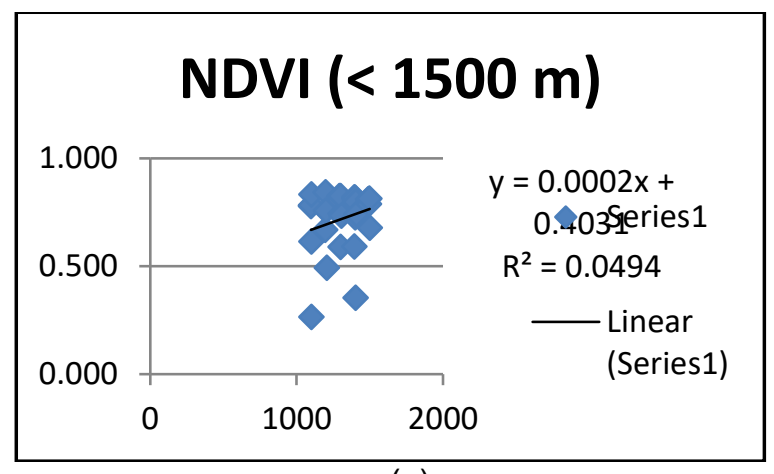

(a)

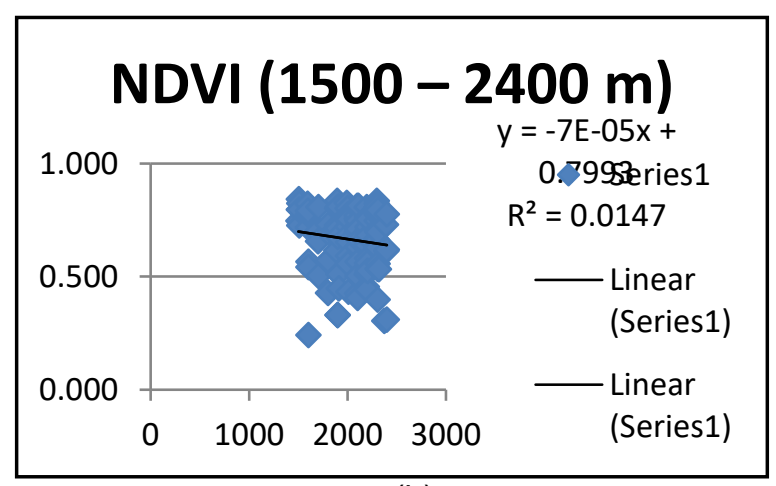

(b)

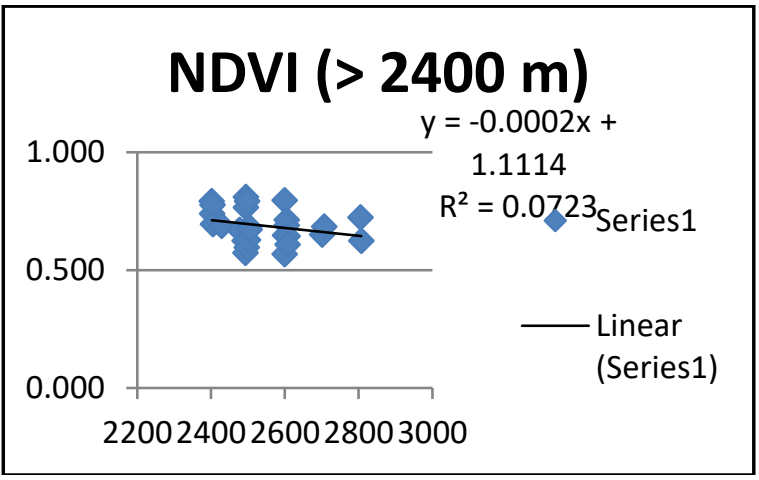

(c)

Gambar 10. Uji Regresi antara ketinggian dan indeks vegetasi pada (a) 1500 meter, (b) 1500 2400 meter, dan (c) lebih dari 2400 meter

\subsection{Data histogram}

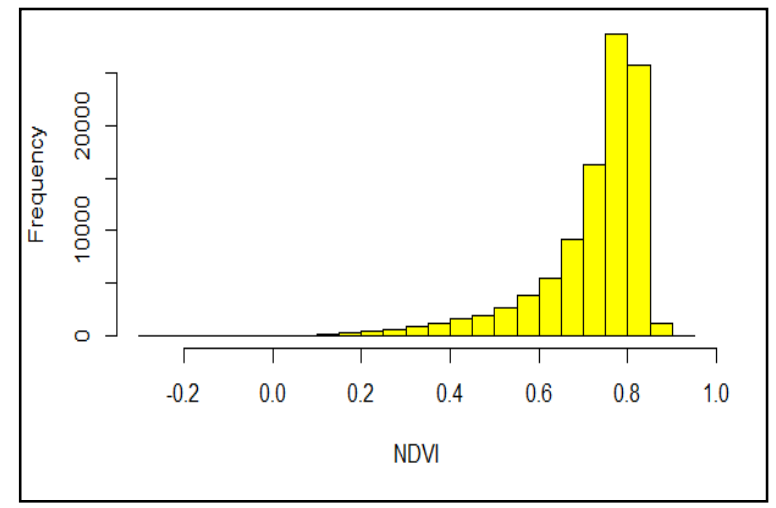

(a)

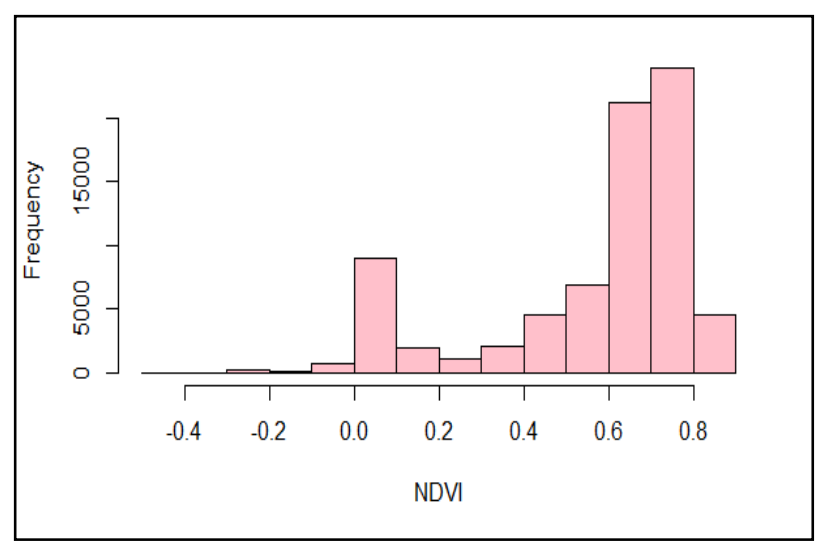

(b)

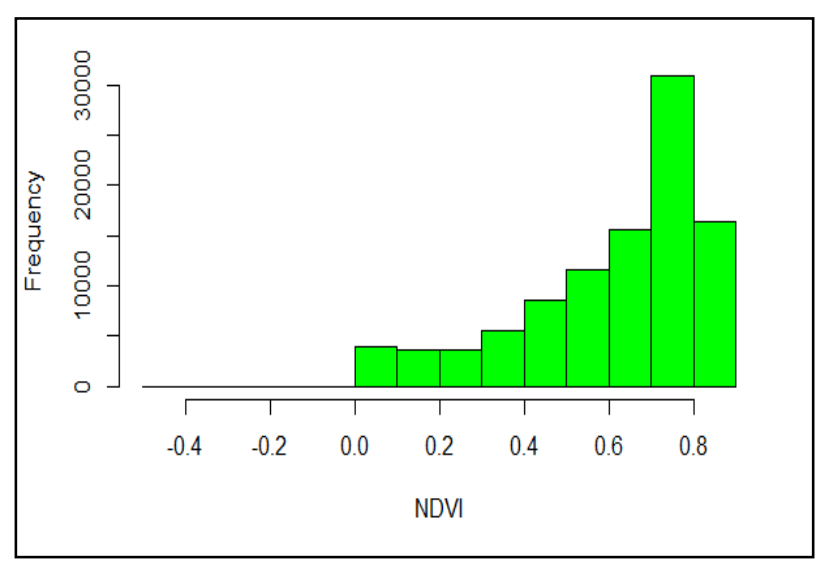

(c)

Gambar 11. Data histogram indeks vegetasi pada (a) Ketinggian 1500 meter, (b) Ketinggian1500 2400 meter dan (c) Ketinggian lebih dari 2400 meter

Dari data histogram tersebut, dapat diketahui besaran nilai NDVI disetiap zona ketinggiannya. Terlihat bahwa nilai indeks vegetasi di zona $<1500$ $\mathrm{m}$ memiliki nilai indeks vegetasi yang lebih beragam dibandingkan kedua zona lainnya. Karena diketinggian tersebut, lebih banyak jenis vegetasi yang tumbuh di tempat tersebut.

\section{KESIMPULAN}

Studi yang dilakukan untuk melihat relasi antara indeks vegetasi dan zona ketinggian di Taman Nasional Bromo Tengger Semeru memberikan sejumlah kesimpulan bahwa: variabel DEM dan NDVI memiliki tingkat korelasi yang rendah sebesar 0,0494 pada ketinggian < $1500 \mathrm{~m}$ (zona submontana), 0,0147 pada ketinggian $1500-2400 \mathrm{~m}$ (zona Montana), dan 0,0723 pada ketingain $>2400$ m (zona sub - alpin). Secara visual penyebaran vegetasi lebih terlihat di daerah dengan ketinggian $<1500$ mdpl. Karena vegetasinya menyebar, menyebabkan nilai histogramnya pun terdistribusi dengan baik. Hal ini berarti semakin tinggi tempat akan menyebabkan kurangnya kerapatan vegetasi. Indeks vegetasi NDVI sebagai representasi kerapatan Vegetasi penutup lahan memiliki hubungan yang searah. Semakin tinggi nilai NDVI, 
maka vegetasi pun akan semakin rapat dan begitu pun sebaliknya.

\section{UCAPAN TERIMA KASIH}

Dengan selesainya penelitian ini, saya mengucapkan terima kasih kepada Bapak Mochamad Firman Ghazali, S.Pd., M.T. selaku dosen pembimbing dan teman teman yang telah membantu dalam mengerjakan penelitian ini

\section{DAFTAR PUSTAKA}

Agc Indonesia. (2010). Retrieved Desember 24, 2019, from https://www.gambar.pro/2010/05/ 82-gambar-hutan-hujan-pegunungan-rendah .html.

Alfarisi. (2012). Vegetasi Hutan Wanagama. Retrieved November 2019, 20, from http://agricultureforlife.blogspot.co.id/2012/0 71.

Arhamsyah, D. (2015). Hutan Pegunungan. Medan: Media Angkasa.

Barr, C., Wollenberg, E., Limberg, G., Anau, N., Sudana, M., Moeliono, M., \& Djogo. T. (2001). The: Impacts of Decentralisation on Forest and $\mathrm{F}$ orest-Dependent Communities in Malinau District, East Kalimantan. Case Studies on Decentralisation and Forest in Indonesia. Case Study 3. CIFOR

Departemen Kehutanan. (2009). Profil Balai Besar Taman Nasional Bromo Tengger Semeru. Malang: Departemen Kehutanan Direktorat Jendral Perlindungan Hutan dan Konservasi Alam
Desmann, R. F. (1977). Prinsip Ekologi untuk Pembangunan Ekonomi. Penerjemah: Sumarwoto, O. Jakarta: P.T. Gramedia

Fatma, D. (2017). Klasifikasi Iklim Junghuhn. Jakarta: IImu Geografi.

Ghazoul J., \& Sheil D. (2010). Tropical Rain Forest Ecology, Diversity and Conservation. Oxford: Oxford Univ. Press.

Lillesand \& Kiefer. (1997). Penginderaan Jauh dan Interpretasi Citra. Dulbahri (Penerjemah). Gadjah Mada University Press, Yogyakarta.

Mackinnon, K. G. (2000). Ekologi Kalimantan Buku III. Jakarta : Prenhallindo.

Marsono, D. (1977). Deskripsi Vegetasi dan Tipetipe Vegetasi Tropika. Yayasan Pembina Fakultas Kehuatanan UGM.

Rouse, J. W., Haas, R. H., Schell, J.A., \& Deering, D.W. (1974). Monitoring vegetation systems in the Great Plains with ERTS. Paper presented at the 3rd ERTS-1 Symposium, Greenbelt, Maryland.

Ryan, L. (1997). Creating a Normalized Difference Vegetation Index (NDVI) image Using MultiSpec. University of New Hampshire.

Suastini, (2015). Klasifikasi Iklim Junghuhn. Jakarta: Angkasa Indah

Sulistyono. (1995). Pengaruh tinggi tempat terhadap Pinus merkusii Jungh et de Vriese di KPH Probolinggo Perum Perhutani Unit II Jawa Timur. 